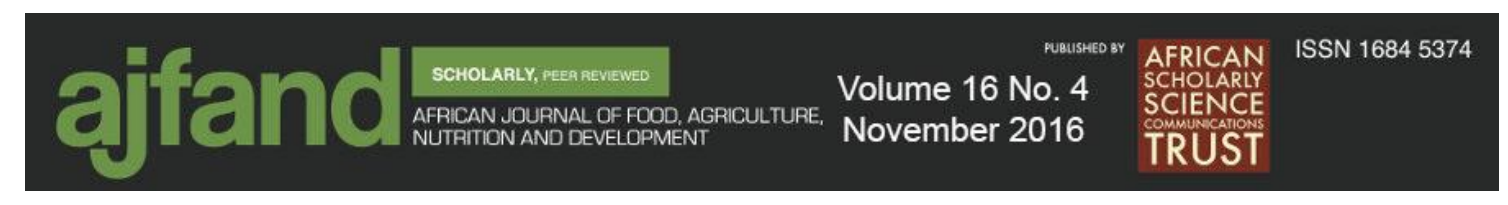

DOI: 10.18697/ajfand.76.15540

\title{
USING FARMER-PRIORITIZED VERTISOL MANAGEMENT OPTIONS FOR ENHANCED GREEN GRAM AND TOMATO PRODUCTION IN CENTRAL KENYA
}

Wamari JO' ${ }^{*}$, Macharia $\mathrm{JMK}^{2}$ and IV Sijali ${ }^{1}$

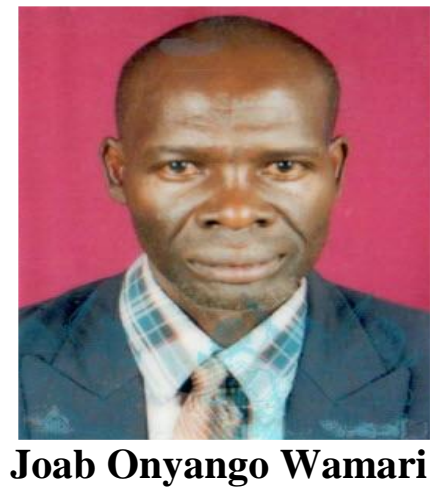

*Corresponding author email: joabwamari@yahoo.com

${ }^{1}$ Kenya Agricultural \& Livestock Research Organization (KALRO), National Agricultural Research Laboratories, P.O. Box 14733-00800 Nairobi, Kenya

${ }^{2}$ National Fibre Research Centre, P.O. Box 298-10300, Kerugoya, Kenya 


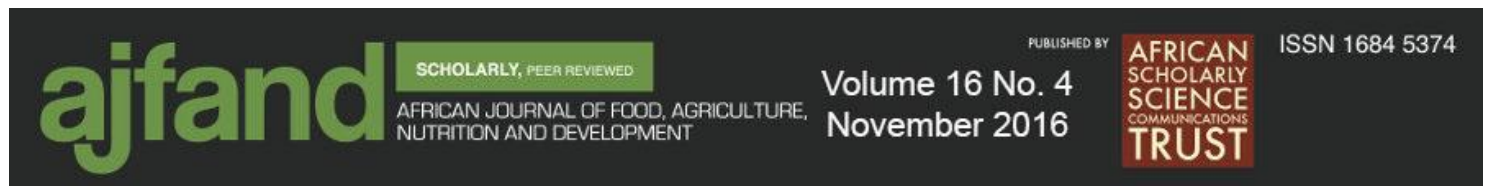

\section{ABSTRACT}

Green gram (Phaseolus aures L.) and tomato (Solanum lycopersicum L) are widely grown in the vertisols of the Mwea Irrigation Scheme in Kenya alongside the rice fields. Green gram can fix nitrogen and is grown for its highly nutritious and curative seeds while tomato is grown for its fruit rich in fiber, minerals and vitamins. The two can be prepared individually or together in a variety of ways including raw salads and/or cooked/fried. They together form significant delicacies consumed with rice, which is the major cash crop grown in the black cotton soils. The crops can grow well in warm conditions but tomato is fairly adaptable except under excessive humidity and temperatures that reduce yields. Socio-economic prioritization by the farming community and on-farm demonstrations of soil management options were instituted to demonstrate enhanced green gram and tomato production in vertisol soils of lower parts of Kirinyaga County (Mwea East and Mwea West districts). Drainage management was recognized by the farming community as the best option although a reduced number of farmers used drainage and furrows/ridges, manure, fertilizer and shifting options in that descending order. Non-availability of labour and/or financial cost for instituting these management options were indicated as major hindrances to adoption of the yield enhancing options. Labour force was contributed to mainly by the family alongside hiring (64.2\%) although $28 \%$ and $5.2 \%$, respectively used hired or family labour alone. The female role in farming activities dominated while the male role was minimal especially at weeding. The youth role was insignificant and altogether absent at marketing. Despite the need for labour at earlier activities (especially when soil management options needed to be instituted) it was at the marketing stage that this force was directed. Soils were considered infertile by $60 \%$ but $40 \%$ indicated that their farms had adequate fertility. Analysis showed that with ridging, farm yard manure and fertilizer improved soil fertility, crop growth and income considerably. Phosphate and zinc enhancement reduced alkalinity and sodicity. Green gram and tomato yields increased under ridges and farm yard manure application by between $17-25 \%$ which significantly enhanced household incomes.

Key words: Green gram, Tomato, Vertisol management, Household income, Mwea, Kenya 


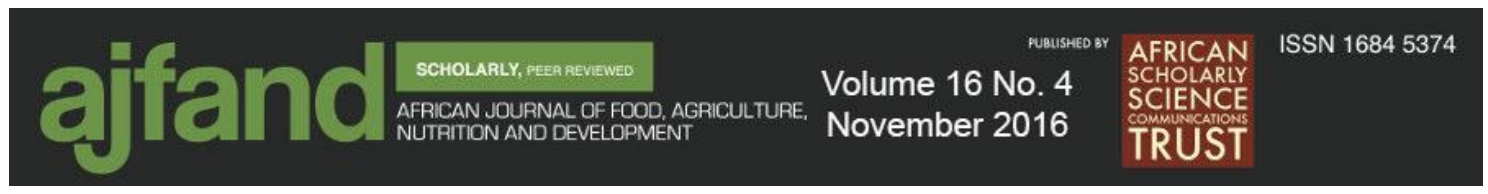

\section{INTRODUCTION}

Green gram (Phaseolus aures L.) and tomato (Solanum lycopersicum L) are widely grown in the vertisols of the Mwea Irrigation Scheme alongside the rice fields in Kenya. While green gram is grown for its seeds, which is highly nutritious, tomato is grown for its fruit and both can be prepared together to form various delicacies. Green-gram contains at least some of every type of amino-acid and is rich in Calcium, Phosphorus, Magnesium and Folate and Vitamins A and C [1]. It also has low fat protein (14g per cup), high fiber (15g per cup) and low glycemic that lowers risk of diabetes and is easily digestible. It also has several curative abilities and is useful for the sick (cholera), expectant and lactating mothers. The crop can also fix nitrogen and is adaptable to drought conditions and inferior soils [1]. Tomato has fiber, minerals and vitamins $\mathrm{C}$ and $\mathrm{K}$ and is used as raw salads and/or cooked/fried with most vegetables [2]. It has antioxidants that have curative abilities against cancers such as those of the breast, colon and prostate and grows well in warm conditions but is fairly adaptable except under excessive humidity and temperatures that reduce yields [2].

Vertisols and vertic soils, which are associated with glaring limitations to crop production due to their chemical and physical properties, cover 43 million hectares in 28 countries in Africa [3]. These and other associated soils in the highlands of East Africa occur at altitudes of 1000-3000 m above sea level and in Kenya occupy 5\% of the country's landmass (2.8 million hectares), of which about $80 \%$ is located in Arid and Semi-Arid Lands (ASALs) [4]. In these areas, mean monthly maximum temperatures rarely exceed $30^{\circ} \mathrm{C}$ and the minimum temperature is usually below $15^{\circ} \mathrm{C}$. In the single peaked rainfall areas, the temperatures are relatively high during March and May. In the rainy months of June to September, the mean maximum temperature is around $20^{\circ} \mathrm{C}$. In the highlands of East Africa receiving bimodal rainfall (example Nairobi, Kenya), temperatures are more or less uniform throughout the year [5].

Some of the most common management problems of vertisols include: poor drainage and water logging, run-off and soil erosion, difficult tillage and unsuitable land preparation implements and low organic carbon and nitrogen $[4,5]$. There are various challenges and limitations encountered while attempting to use vertisols related to their associated shrinking, swelling and cracking dynamics that need to be taken into account $[6,7]$. Jutzi [7] and Baudyapadhyay et al. [8] outline conservation of water using tied-ridges, excess water storage and evacuation, gulley control and split-application of nitrogenous fertilizers as options for enhancing productivity of vertisols.

Macharia et al. [9] attempted to develop an appropriate drainage system to remove surplus water early in the season to allow early and timely planting of crops for maximum yield, to develop an appropriate land-shaping implement for effecting the removal of surplus soil surface water, and to determine economically suitable fertilizer types and rates for application on different crops grown. One option they recommend is that of addressing water harvesting and drainage issues tackled together in dry-land vertisol areas. This should be followed by the introduction of crops tolerant to water logging and perennial fruit trees. Animal power has been suggested to be able to reduce labour requirements for "early" (before rainfall onset) land preparation and instituting additional 
structures amongst other required activities [11]. This option can, however, also be challenging since even the livestock may be too weak due to shortages of pasture preceding the on-coming season. It is, therefore, particularly commendable to use lowcost and readily available inputs (fertility, labour) especially noting the usually low resource availability amongst the populations residing in semi-arid areas in Africa [12]. Vertisols in semi-arid lands in the Ethiopian highlands have been reported to be able to sustainably produce at least two crops per year when correct and timely management options are pursued; that is, use of ox-plough for land preparations to enhance surface drainage and using new cropping systems such as low cost phosphate sources and legumes for nitrogen [13]. Virmani [5] indicates that the appropriate functionality of vertisols would depend on cultural, socio-economic and ecological potential of any targeted area.

The usual vertisol problems include impeded drainage; water-logging and hence late post rain planting; run-off and soil erosion; difficult tillage and unsuitable implements and low organic carbon and nitrogen [10]. In an attempt to overcome these problems, there is widespread use of animal power for tilling. Land preparation can only commence after the first rains when the soil can be penetrated by the plough, so plough/planting is practiced and a secondary pulse crop is planted two or three weeks later. The difficulties associated with these vertisols usually causes delayed planting with resulting loss in yield potential. It is, therefore, pertinent to identify a mechanized means for land preparation. A tractor hire service for each country could essentially solve this problem. Investigations on vertisol management in Kenya have previously focused on influencing biophysical characteristics with a test crop to determine if these lead to any changes in crop performance [13].

Previously, some management strategies have been attempted including a feasibility study in 2010-2012 [13]. Later water harvesting was done by use of constructed water pans using soil compaction instead of sheet linings. These were not successful because the vertisols were found to be 3 meter deposits overlying highly filtrating soils. Also attempted was installation of Polyvinyl chloride (PVC) pipes from the major rivers to irrigate these areas for crop productions but there were financial constraints. Food crops grown in the areas in order of importance include maize, beans, bananas, fruit trees, rice alongside a number of horticultural crops. However, the water working water pans $\left(5,000 \mathrm{~m}^{3}\right)$ constructed in April 2012 can provide sources of water used in these particular proposed activities.

This work entailed an intervention study of vertisol management options which address problems of water-logging, low fertilizer response and low fertility through instituting ridges and application of nitrogen fertilizers and farm-yard manure (FYM). The target area was lower Kirinyaga County (Mwea East and Mwea West districts) where vertisols occupy over $50 \%$ of the districts. The objective of the work was to evaluate biophysical and economic implications of using prioritized-vertisol management options in Mwea. Specifically, this included: investigating using a check-list, the socio-economic problems associated with green gram and tomato production in vertisols, demonstrating a handful of the vertisol management options with farmers and other stakeholders and show-casing enhanced soil, crop and economic characteristics associated with management options. 


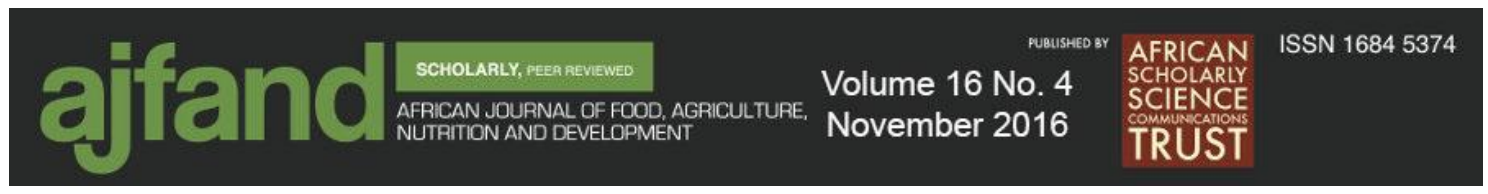

\section{MATERIALS AND METHODS}

\section{Study Area}

The area of study was Kirinyaga Central district which covers some $35,880 \mathrm{~km}^{2}$, and was targeted as a pilot vertisol covered area. The district has a population of 104,437 with a density of 733.2 persons per square $\mathrm{km}$. This mainly lie across a number of agroecological zones namely Upper Midland (UM1), Lower Highland (LH1), and Tropical Alpine zones in the upper reaches of the district. Vertisols in Kirinyaga Central occur in two locations namely Kanyekini and Koroma, which cover some 11,840 $\mathrm{Km}^{2}$ about $30 \%$ of the total area. The experiments were laid in the vertisol areas of Kirinyaga County where farmers practice rain-fed subsistence farming. Farmers mainly grow maize, green grams, cowpeas and tomatoes. Table 1 shows some selected population characteristics of vertisol-occupied zone in Kirinyaga.

\section{Survey using check list}

A checklist developed through consultations with the scientists, extension and administrative personnel and farmers themselves, and which attempted to address socioeconomic aspects related to general management of vertisols, was administered to a sample of 95 farmers (which was $63.3 \%$ of the targeted number of 150) in the vertisoloccupied area. The 3,924 households whose names were provided by the local extension officer were assigned numbers between 1 and 3,924 and randomized using computer generated random numbers. The 150 intended interviewees were picked of every 27 th household and were deemed to be representative of the residents. Although attempts were made to interview all the intended farmers, this was not possible due to limited time and financial resources. The sampled farms were surveyed for the institution of the on-farm demonstrations and results were deemed to represent the household characteristics in the target area. Administering of the questions was done by the scientists, local technical assistants and extension personnel. The Statistical Package for Social Sciences (SPSS) Version 20 package was used to analyze the data by a socio-economist.

\section{On-farm demonstrations}

Two (2) trials were instituted in three seasons: 2 in the long (March-June) rains of 2013 and 2014 and 1 in the short (November-February) rains 2013/14 at Mwea East and Mwea West Districts belonging to identified farmers' groups which were Kiamanyeki United in Mwea East, and Ngothi Village Self-help group (SHG) in Mwea West. Green grams were used as the test crop at Kiamanyeki while tomato was used at Ngothi. The 2 groups represented a total of 90 households (total member within the groups). Three vertisol management strategies were laid at each of the sites represented by the farmers' groups. These were represented by (a) Farmer practice; (b) Ridges + Di-ammonium phosphate (DAP) and (c) ridges + FYM + DAP in 10 by 10 m plots. See figure 1.

The test crops used were green grams (Variety N26) and tomato (Safari variety). Ten (10t/ha) of FYM was provided by the farmer/farmers' groups and was ploughed into the plot before planting. The spacing for the green grams was $45 \times 20 \mathrm{~cm}$ while the tomato was spaced at $100 \times 50 \mathrm{~cm}$ and these crops specific inter-row spacing constituted the ridge spacing in the two ridging plots. The green gram rows were 15 while those of the 


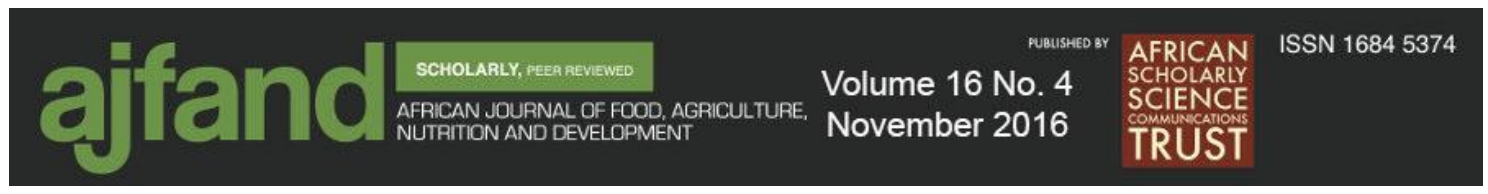

tomato were 14 . The ridges were also constructed as per crop spacing with at least $12 \mathrm{~cm}$ height. Di-Ammonium Phosphate (DAP) was applied at $70 \mathrm{~kg} \mathrm{ha}^{-1}$ at planting and sowed on the slope of the ridges. The depth of the ridges was at least $12 \mathrm{~cm}$ and the planting of the seed was done on the slope of the ridges (neither on top nor on the bottom of the ridges). Crop protection schedule was carried out as the need arose with pesticides that were provided.

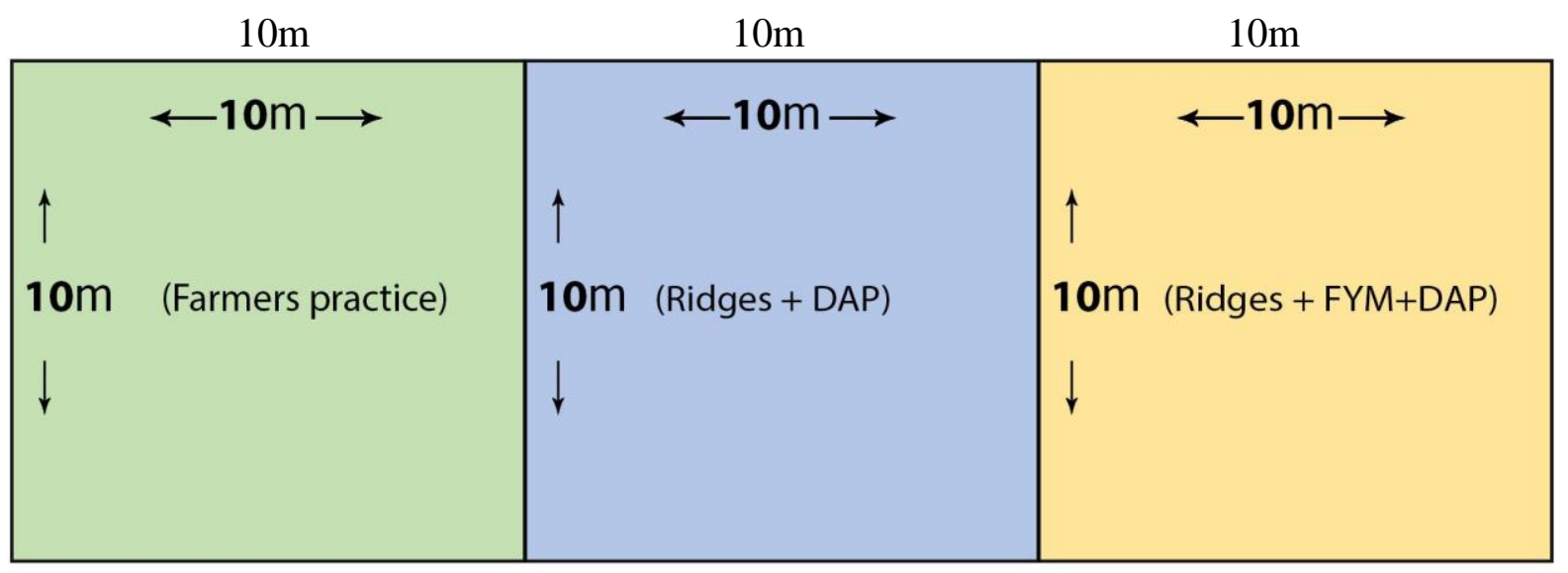

Figure 1: Treatments of the Vertisol trials

Farm yard manure (FYM) was applied at the rate of $70 \mathrm{~kg}$ per plot, which is the equivalent of the documented recommended rates of $20 \mathrm{t} \mathrm{ha}^{-1}$ and was provided by the farmers. This was applied and dug into the soils before instituting the ridges and furrows for sowing the seeds. Basal DAP fertilizer was applied at planting in the two intervention plots at the rate of $70 \mathrm{~kg}$ per hectare. The farmer practice plot remained as whatever they usually do in their farms.

A baseline soil fertility characterization of the experiment was done to determine if there were any changes in soil fertility status as a result of interventions instituted. Additional soil samples were taken to determine changes, if any, for analysis.

The following data was collected from plots:

1. Planting date of crop variety

2. Days to emergence

3. Plant height (30 days after emergence (30 DAE)

4. Days from planting to $50 \%$ flowering (only two crop rows were used with a definite (for example 10 plants) number of crops being observed). When half of these had evidence of flowering that was entered as the date of flowering

5. Harvesting date (This is the date of first harvest in case of tomatoes).

Economic evaluation, that is crop yields obtained, costs of production (including fertilizers prices, and labour input for its application, cost of farm yard manure and its application, and labour for instituting ridges) was carried out to determine effects of different instituted management options. Some costs remained constant in all the three plots and were, therefore, not included in the calculation. These included, land preparation, planting, spraying, weeding and harvesting. 


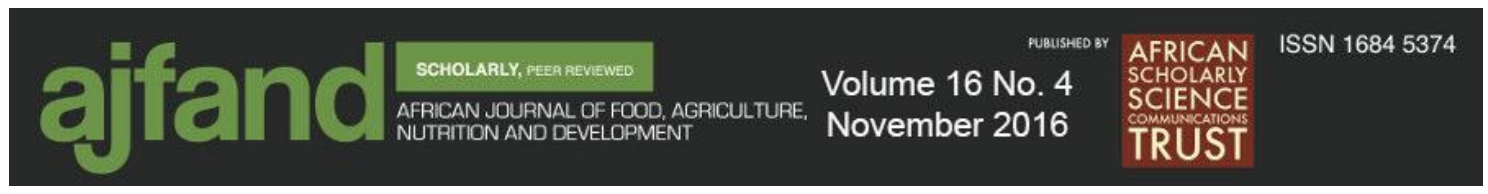

\section{RESULTS}

\section{HOUSEHOLD CHARACTERISTICS}

About $80 \%$ of the farmers interviewed were male while the rest were female. Farms which were mainly hired $(82 \%)$ varied in size between 2 to 8 acres with the majority falling between 2 to 5 acres half of which was used for farming by all the households. Household sizes varied between 1 and 8 with $37 \%$ having five members each. Majority of the households ( $80 \%$ ) had between 2 and 5 persons with other categories having fewer members. See figure 2.

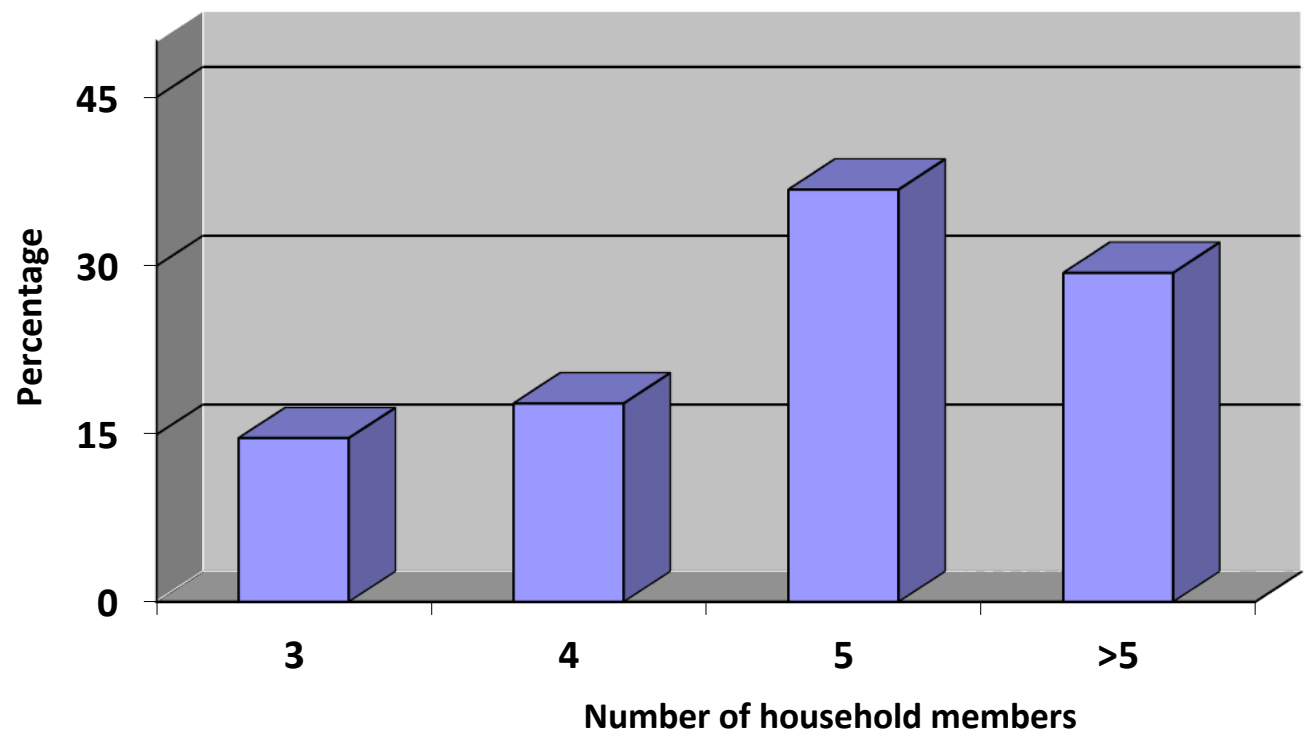

Figure 2: Categories of household composition in Mwea

\section{Crop choices}

The farmers reported growing rice (about 60\%), maize (23\%), tomato (13\%) and green gram $(3.1 \%)$ as main crops in declining order of importance. These crops were grown mainly for generation of income $(54.7 \%)$ and food $(29.4 \%)$. Figure 3 shows green grams grown under farmer practice. Appropriate agronomic practices (use of certified seed, nutrition, moisture and pest management and cropping pattern) are important requirements for managing utilization of vertisols. 

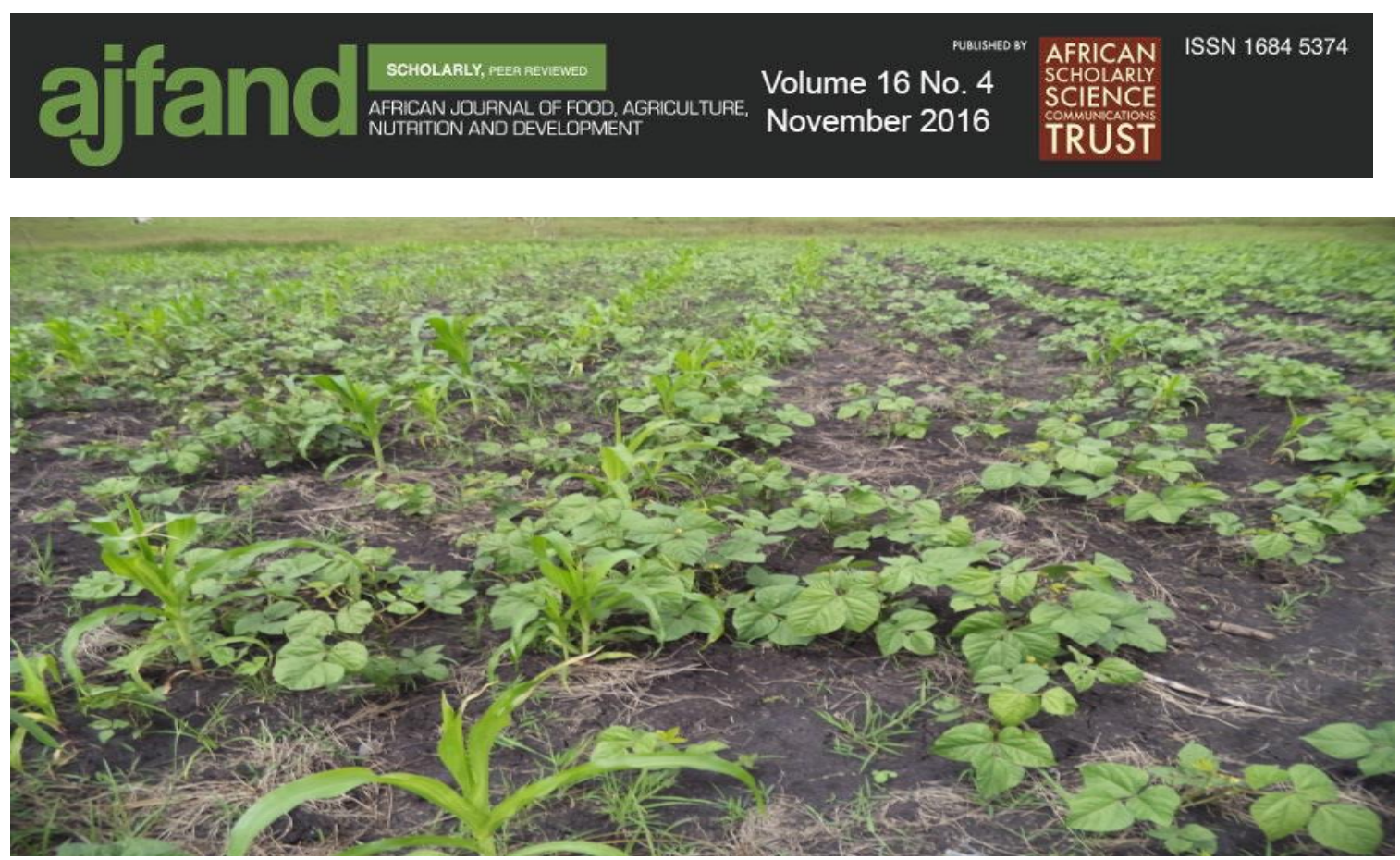

Figure 3: Green grams showing farmers' practice

\section{Management options}

The management options that would be instituted and are popular included structures such as ridges and furrows, fertilizers and manure or their combinations against farmers' current practice to compare crop performance and soil physical characteristics. Nine management options were identified by farmers as indicated in Table 2 with manure/FYM, drainage, fertilizer and shifting options being used in decreasing order of frequency.

\section{Source of labour}

While $64.2 \%$ of the farmers used both hired and family labour, $28 \%$ and $5.2 \%$, respectively used hired or family labour alone. Supplementing labour was recognized as a yield-enhancing option except for two farmers who said they did not believe this would be the case. Of the farm activities males dominated while females and youth disappeared almost completely at marketing. The male role was minimal at weeding while the youth role remained insignificant and altogether absent at marketing. See Table 3.

Eighty-four per cent of the farmers, however, did not indicate constraints in labour with only $15 \%$ recognizing that as a constraint. Seventy-four percent used the ox-plough while $25.2 \%$ used both the plough and hand labour. There were no constraints in accessing and/or controlling animal power in 50 households while 44 households had some difficulty in accessing these.

\section{Tools}

No issues arose due to hire and maintenance costs of tools in majority of the households except one where this problem arose while no credit facilities existed for these services. Spares for tools were expensive and lowering these costs was suggested as a measure to sort this. 


\section{Fertility}

On fertility, $60 \%$ said their soils were not fertile enough while $40 \%$ indicated enough fertility. However, all used fertilizers of one form or a combination of various types. Seventeen households prioritized the use of CAN while 40 households used mainly Sulphate of Ammonium (SA). Di-ammonium phosphate (DAP), Muriate of Potash (MOP), and Mavuno were also used and in each case the farmers indicated these would improve soils for better crops.

\section{ON-FARM DEMONSTRATION}

\section{Crop performance}

Table 4 shows the results of the on-farm demonstration plots obtained. The plant height for green grams (Kiamanyeki) was higher in the two intervention plots by 4.5 and 10.0 $\mathrm{cm}$ for treatments 2 and 3 and yields were higher, that is $123 \%$ and $82 \%$, respectively. There was, however, no difference in days-to-flowering in the three treatments. At Ngothi, although the tomato plant heights were lower for the intervention plots, the plants under treatment 3 flowered later and yielded higher (38 and 76\%).

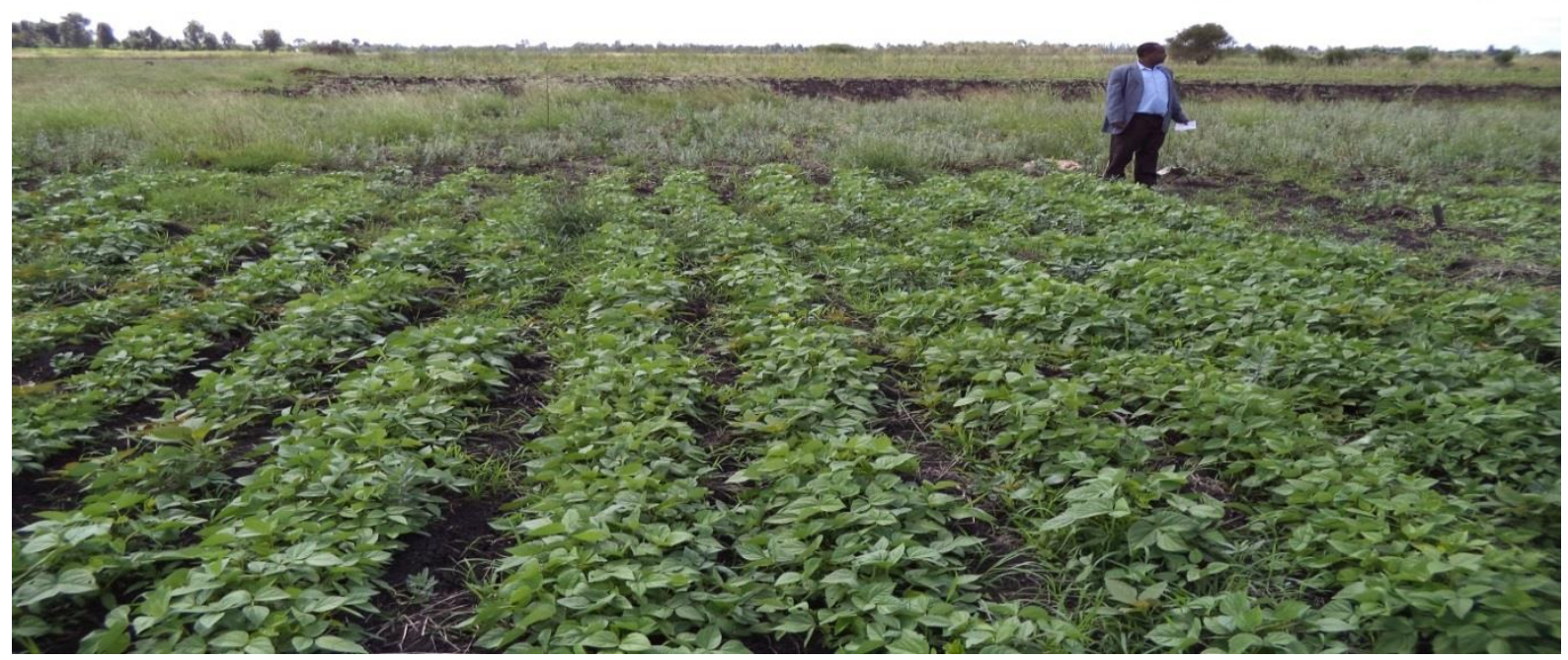

Figure 4: Well managed green gram field (Notice poorer performance mid-left)

Table 5 shows some differences shown in the various management options. In all cases the combination option of Ridging-FYM-DAP had enhanced characteristics.

\section{Economic evaluation}

Results of economic evaluation are shown in Table 6. With farmers' practice whereby local seed is used and neither FYM, DAP nor ridging is done, there was yield of 2.1 and $1.7 \mathrm{t} / \mathrm{ha}$ of tomato and green gram, respectively. When, however, ridges were instituted along with DAP the yields jumped to 3.8 and $2.9 \mathrm{t} /$ ha for the respective crops and brought an additional income of Ksh 467, 695 (USD 4585) and 104, 345 (USD 1023) for ridging and DAP and Ksh 397, 930 (USD 3901) and 134,880 (USD 1322) per acre for ridging, 


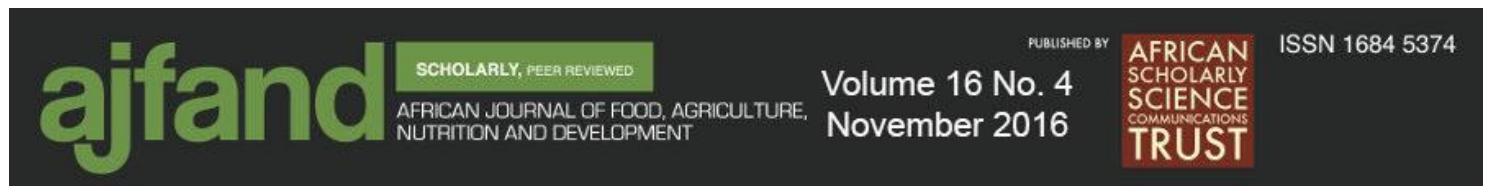

FYM and DAP for the respective crops. These translated to $178 \%$ and $143 \%$ and $144 \%$ and $185 \%$ more income for the respective intervention options and crops.

\section{DISCUSSION}

\section{SOCIO-ECONOMIC EVALUATION}

In view of the farm sizes being predominantly small (2-5 acres), it is important that there are significant economic returns to the management interventions used. The enhanced productivity reported would have higher impact in male-headed $(80 \%)$ households compared to female-headed households (20\%), and in hired farm-holds (82\%) more than in self-owned farm-holds since the latter form only a small percentage (18\%) in this area. It is recommended that high-value crops like tomato be grown in order to realize the areas' potential for alleviating the prevalent food insecurity. Other reasons given by farmers for choice of crops they grew included resistance to water logging, suitability for the environment and higher yields. International Soil Reference and Information Centre [16], for example, also report increased wheat and hoarse bean yields of 150 and 300\%, respectively under improved vertisol management options.

\section{Management options}

Despite having a number of management options (9) at the farmers' discretion (see table 2 ) only a reduced number used drainage and furrows/ridges while a higher number used manure, fertilizer and shifting options. It is necessary to institute strategies in farmers' fields with a quick maturing crop variety (green grams) since rice is already established and researched on by Mwea Integrated Agricultural Development (MIAD) Centre working within the National Irrigation Board(NIB).

\section{Labour}

High labour demand and cost for instituting these vertisol management options was mentioned by all the farmers as a hindrance to adoption but they were recognized as yield enhancing options except for two farmers who mentioned that these would not enhance yields. Due to the labour constraints, instituting and maintaining ridges as a management option would be most sustainable for households having 5 members per household that is $37 \%$ of the population (142 households) assuming the household members are available and capable to carry out the said activities. See also figure 1.

Despite the need for labour at earlier farm activities (especially when management options need to be instituted) it was at the marketing stage that this force was directed. Goe [17], Jutzi et al. [18] and Macharia et al. [9] have indicated animal traction and improvised plough implements to, respectively enhance land preparation and ridging and eventual yield improvement in vertisols. The males dominated all the farming activities while females were virtually absent at the marketing stage. The male role was further minimal at weeding while the youth role remained insignificant and altogether absent at marketing. See Table 3. 


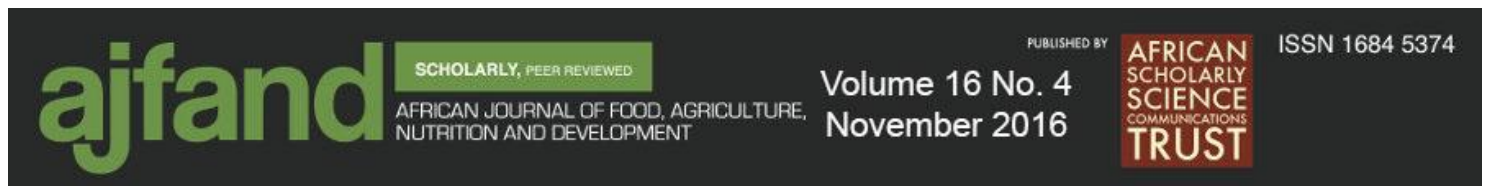

\section{ON-FARM EVALUATION}

The plant height for green grams (Kiamanyeki) was generally higher in the ridging + DAP and the Ridges + DAP + FYM treatments. This can be attributed to better nutrition and water management in the two intervention plots. At Ngothi these two interventions extended the flowering period and ensured higher tomato yields. Slight improvements in soil chemical characteristics were also reported of $\mathrm{pH}$, total nitrogen $(\mathrm{N})$, organic carbon $(\mathrm{C})$, potassium $(\mathrm{K})$ and calcium $(\mathrm{Ca})$ but also major economic returns as indicated in tables 5 and 6, respectively. Ikitoo [14, 19] and Sigunga [15] report similar enhanced crop performance and yields in variously managed vertisols in Kenya.

\section{CONCLUSION}

The socio-economic survey reveals that challenges associated with crop production in vertisols are dependent on household characteristics such as members per household, farm sizes and the manner in which family and hired labour is utilized. Interventions should, therefore, target medium sized farm-holds (2-5 acres), the youth and households with 5 members per household to have high impact.

Despite having several soil management options at the farmer's disposal, the few simple manageable agronomic combinations demonstrated in this study can be up/out scaled under the farmers' socio-economic conditions by stakeholders for adoption.

Clear improvements in soil conditions and enhanced crop production due to institution of these management options could absorb labour demands but also enhance economic status of farming households living in vertisols of this area.

\section{ACKNOWLEDGEMENTS}

The authors greatly appreciate the funding provided by the KALRO/Kenya Agricultural Productivity and Agribusiness Project (KAPAP) Activity No. 5.2.2.1 of the Natural Resource Management Programme. The local extension agents especially Mr. Ibrahim Gitari was especially instrumental in day-to-day management of the trials. The Managing Director KALRO kindly accepted the publication of the paper. We also acknowledge the KALRO Irrigation, Drainage and Management of Problem Soils Programme for financing the journal paper publication. 


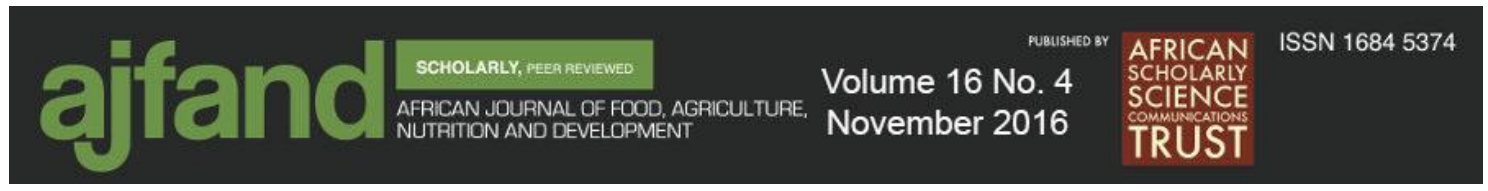

Table 1: Selected household characteristics in vertisol occupied target area

\begin{tabular}{|c|c|c|c|c|c|}
\hline District & \multirow{2}{*}{ Division } & Total area & \multicolumn{3}{|c|}{ Targeted } \\
\cline { 4 - 6 } & & $\mathrm{Km}^{2}$ & Area & Population & Households \\
\hline Mwea & Tabere & 512,800 & 85,300 & 9818 & 2688 \\
East & & & & & 1236 \\
\hline $\begin{array}{c}\text { Mwea } \\
\text { West }\end{array}$ & Kangai & 39,300 & 13,100 & 3719 & \\
\hline
\end{tabular}

Table 2: Vertisol management options in Mwea: Results from survey

\begin{tabular}{|c|c|c|c|c|}
\hline Management option & \# responses & \% & $\begin{array}{c}\text { \# using } \\
\text { options }\end{array}$ & $\%$ \\
\hline Drainage & 61 & 64.21 & 27 & 28.42 \\
\hline Manure/FYM & 14 & 14.73 & 42 & 44.21 \\
\hline $\begin{array}{c}\text { Fhift planting options } \\
\text { (including, population, } \\
\text { planting date etc) }\end{array}$ & 4 & 4.22 & 14 & 14.73 \\
\hline $\begin{array}{c}\text { Water harvesting/Irrigation } \\
\text { Ridging/Furrows/Terraces }\end{array}$ & 2 & 2.11 & 7 & 7.36 \\
\hline Use tolerant/Suitable crops & 1 & 4.22 & Not mentioned & NA \\
\hline $\begin{array}{c}\text { Avoid use of un-favorable } \\
\text { area/period }\end{array}$ & 2 & 2.11 & 1 & 1.11 \\
\hline Use tractor/Ox plough & 1 & 1.05 & Not mentioned & NA \\
\hline
\end{tabular}

$* 4.19 \%$ of the respondent farmers did not use any vertisol management option

FYM- Farm yard manure, NA - Not applicable 


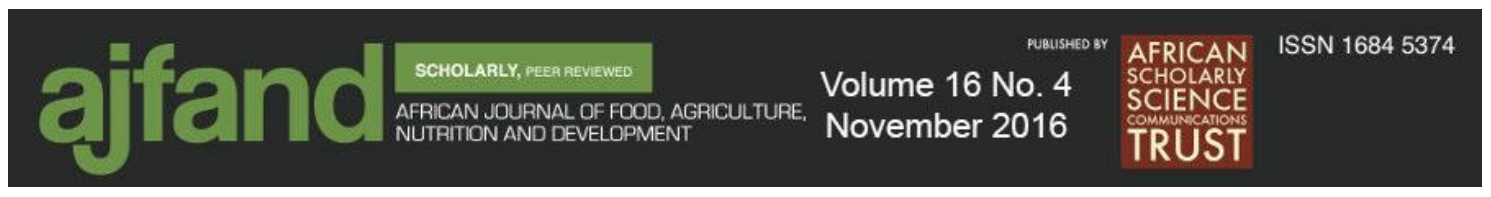

Table 3: Distribution of gender roles in various activities in Mwea

\begin{tabular}{|c|c|c|c|}
\hline Activity & \% Male & \% Female & \% Youth \\
\hline $\begin{array}{c}\text { Land } \\
\text { preparation }\end{array}$ & 66.3 & 25.3 & 2.1 \\
\hline Planting & 55.8 & 37.9 & 3.2 \\
\hline Weeding & 52.6 & 38.9 & 3.2 \\
\hline Harvesting & 54.7 & 41.1 & 3.2 \\
\hline Marketing & 90.5 & 6.3 & 0.0 \\
\hline
\end{tabular}

Table 4: Agronomic results of on-farm trials in Mwea

\begin{tabular}{|c|c|c|c|c|c|c|}
\hline Treatment & Farm/Site & $\begin{array}{c}\text { Planting } \\
\text { date }\end{array}$ & $\begin{array}{c}\text { Plant } \\
\text { height } \\
\text { (cm) }\end{array}$ & $\begin{array}{c}\text { Days to } \\
\text { flowering }\end{array}$ & $\begin{array}{c}\text { Days to } \\
\text { maturity }\end{array}$ & $\begin{array}{c}\text { Yield } \\
\text { ton/ha }\end{array}$ \\
\hline $\begin{array}{c}\text { Farmers } \\
\text { practice (1) }\end{array}$ & Kiamanyeki & $16 / 04 / 2013$ & 12.5 & 44 & 91 & 1.7 \\
\hline $\begin{array}{c}\text { Ridging } \\
\text { and DAP }\end{array}$ & Kiamanyeki & $16 / 04 / 2013$ & 17.0 & 44 & 91 & 3.8 \\
\cline { 2 - 7 } $\begin{array}{c}(2) \\
\text { Ridges } \\
\text { +FYM } \\
\text { +DAP (3) }\end{array}$ & Kgothi Farm & $22 / 04 / 2013$ & 11.0 & 49 & 96 & 2.9 \\
\cline { 2 - 7 } & Ngothi Farm & $22 / 04 / 2013$ & 9.0 & 52 & 98 & 3.7 \\
\hline
\end{tabular}

FYM- Farm yard manure

DAP- Di-Ammonium Phosphate 


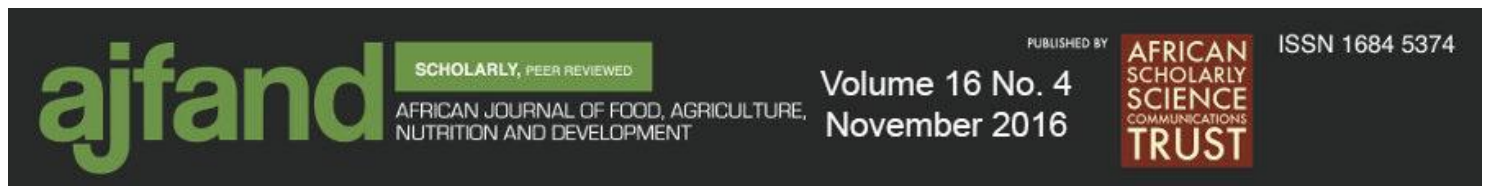

Table 5: Intervention-enhanced soil chemical characteristics at Mwireri farm

\begin{tabular}{|c|c|c|c|c|}
\hline \multicolumn{2}{|c|}{ MANAGEMENT PRACTICE } & $\begin{array}{c}\text { Ridges } \\
\text { + DAP } \\
\text { + FYM }\end{array}$ & $\begin{array}{c}\text { Ridges } \\
+ \text { DAP }\end{array}$ & $\begin{array}{c}\text { Farmers' } \\
\text { practice }\end{array}$ \\
\hline $\begin{array}{c}\text { FERTILITY } \\
\text { STATUS }\end{array}$ & $\mathrm{pH}$ & 7.34 & 7.46 & 7.29 \\
\cline { 2 - 5 } & Tot Nirogen \% & 0.25 & 0.24 & 0.23 \\
\cline { 2 - 5 } & Org. Carbon \% & 2.44 & 2.35 & 2.30 \\
\cline { 2 - 5 } & Potassium (me \%) & 0.18 & 0.16 & 0.16 \\
\cline { 2 - 5 } & Calcium (me \%) & 9.9 & 8.1 & 5.1 \\
\cline { 2 - 5 } & Manganese (me \%) & 0.33 & 0.29 & 0.23 \\
\cline { 2 - 5 } & Sodium(ppm) & 1.18 & 0.98 & 0.60 \\
\cline { 2 - 5 } & Electrical & 1.04 & 0.72 & \\
\hline
\end{tabular}

KEY: me-milli-equivalent, ppm-parts per million, $\mathrm{mS} / \mathrm{cm}$-milliseconds per centimeter 


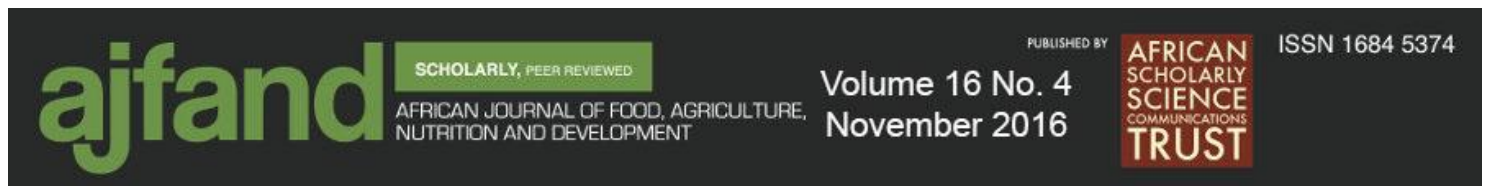

Table 6: Economic evaluation of the instituted options at Mwea

\begin{tabular}{|c|c|c|c|c|}
\hline Interventions & Inputs & $\begin{array}{l}\text { Rate/Unit } \\
\text { used/obtained }\end{array}$ & Cost per unit & Total cost/income \\
\hline Farmers practice & $\begin{array}{l}\text { Seed (green grams) } \\
\text { (Tomato) } \\
\text { Ridging } \\
\text { DAP fertilizer } \\
\text { DAP application } \\
\text { Tomato yield } \\
\text { Green gram yields }\end{array}$ & $\begin{array}{l}0.5 \mathrm{~kg} \\
0.5 \mathrm{~kg} \text { Tin } \\
4 \text { Man days } \\
50 \mathrm{Kg} \\
\text { Man day } \\
2.1 * \text { Tons } \\
1.7 * \text { Tons }\end{array}$ & $\begin{array}{l}\text { Not used } \\
\text { Not used } \\
\text { Not done } \\
\text { Not used } \\
\text { Not used } \\
125,000 \mathrm{KES} \\
\text { 38,500KES }\end{array}$ & $\begin{array}{l}- \\
- \\
- \\
- \\
- \\
262,500 \mathrm{KES} \\
65,450 \mathrm{KES}\end{array}$ \\
\hline Ridges + DAP & $\begin{array}{l}\text { Seed (green grams) } \\
\text { (Tomato) } \\
\text { Ridging } \\
\text { DAP fertilizer } \\
\text { DAP application } \\
\text { Tomato yield } \\
\text { Green gram yields }\end{array}$ & $\begin{array}{l}0.5 \mathrm{~kg} \\
0.5 \mathrm{~kg} \text { Tin } \\
4 \text { Man days } \\
50 \mathrm{Kg} \\
1 \text { Man day } \\
3.8^{*} \text { Tons } \\
2.9 * \text { Tons }\end{array}$ & $\begin{array}{l}400 \mathrm{KES} \\
600 \mathrm{KES} \\
260 \mathrm{KES} \\
2,500 \mathrm{KES} \\
260 \mathrm{KES} \\
125,000 \mathrm{KES} \\
38,500 \mathrm{KES}\end{array}$ & $\begin{array}{l}400 \mathrm{KES} \\
600 \mathrm{KES} \\
1040 \mathrm{KES} \\
5000 \mathrm{KES} \\
260 \mathrm{KES} \\
475,000 \mathrm{KES} \\
111,650 \mathrm{KES}\end{array}$ \\
\hline $\begin{array}{c}\text { Ridges + DAP + } \\
\text { FYM }\end{array}$ & $\begin{array}{l}\text { Seed (green grams) } \\
\text { (Tomato) } \\
\text { Ridging } \\
\text { DAP fertilizer } \\
\text { DAP application } \\
\text { FYM application } \\
\text { Tomato yield } \\
\text { Green gram yields }\end{array}$ & $\begin{array}{l}0.5 \mathrm{~kg} \\
0.5 \mathrm{~kg} \text { Tin } \\
4 \text { Man days } \\
50 \mathrm{Kg} \\
1 \text { Man day } \\
\text { 1Ton } \\
3.1 * \text { Tons } \\
3.7 * \text { Tons }\end{array}$ & $\begin{array}{l}400 \mathrm{KES} \\
600 \mathrm{KES} \\
265 \mathrm{KES} \\
2,500 \mathrm{KES} \\
265 \mathrm{KES} \\
265 \mathrm{KES} \\
25,000 \mathrm{KES} \\
38,500 \mathrm{KES}\end{array}$ & $\begin{array}{l}400 \mathrm{KES} \\
600 \mathrm{KES} \\
1040 \mathrm{KES} \\
5000 \mathrm{KES} \\
265 \mathrm{KES} \\
265 \mathrm{KES} \\
387,500 \mathrm{KES} \\
142,450 \mathrm{KES}\end{array}$ \\
\hline
\end{tabular}

$* 1 \mathrm{~kg}$ of green gram $=38.5 \mathrm{KES}, 1 \mathrm{~kg}$ of tomato $=125 \mathrm{KES} 1 \mathrm{USD}=102 \mathrm{KES}$

DAP- Di-Ammonium Phosphate. FYM- Farm yard manure. KES - Kenya Shilling 


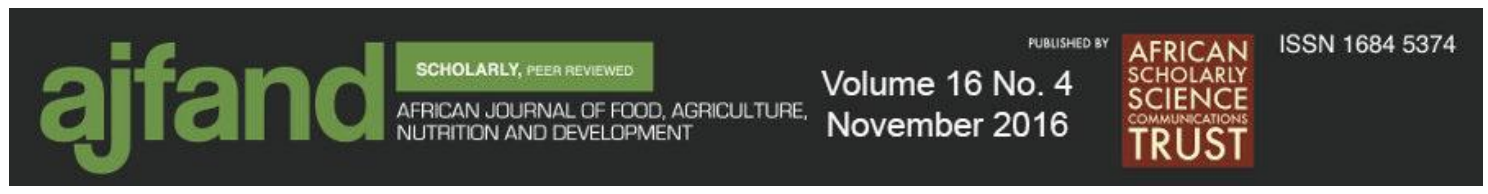

\section{REFERENCES}

1 http://www.oworking.com Green gram health benefits overviews. Accessed on $19^{\text {th }}$ May 2016.

http://www.stylecraze.com/articles/amazing-benefits-of-tomatoes Thirty-two (32) Amazing benefits of tomatoes (Tamatar) for skin, hair and health. Accessed on $19^{\text {th }}$ May 2016.

3 Debele B The Vertisols of Ethiopia: Their Properties, Classification and Management. World Resources Report no. 1983;56: 31-54 FAO Rome.

4 Dudal R and DL Bramao Dark Clay soils of tropical and sub-tropical regions. FAO Agricultural Development Paper no.8: FAO Rome, 1965.

5 Virmani SM Agro-climatology of the vertisols and vertic soils areas in Africa. ICRISAT In: Jutzi, SC, Haque I, McIntire and Staves, J ES. (Eds.). Proceedings on the management of vertisols in sub-Saharan Africa held at ILCA Addis Ababa, Ethiopia between $31^{\text {st }}$ August and $4^{\text {th }}$ September 1987.

Tekele M, Dinky $\mathbf{R}$ and J Lascano Review paper: Challenges and limitations in studying the shrink-swell and crack dynamics of vertisols. Open Journal of Soil Science.2012: 82-90.

$7 \quad$ Jutzi S Deep black clay soils (vertisols): Management options for the Ethiopian highlands. Mountain Research and Development. 1988; 8 (2/3): 153-156.

Baudyapadhaya KK, Mohanty M, Par-nuli DK, Misra AK, Hali KM, Mandal KG, Ghosh PK, Chaudhry RS and CL Acharya Influence of tillage practices and nutrient management on crack parameters in a vertisol of central India. Soil Tillage Research.2003; 71 (2): 133-142.

9 Macharia JMK, Nandwa S and ZA Nyakwara Socio economic study on the potential to introduce, test and enhance adoption of appropriate tools for tilling and draining vertisols in Mbeere District, Eastern Kenya, 1998.

10 Latham M and PM Ahn Networking on vertisol management: concepts, problems and development. IBSRAM In: Jutzi, S.C., Haque I. (Eds.). Utilization of agricultural by-products as livestock feeds in Africa. Proceedings on the management of vertisols in sub-Saharan Africa held at ILCA Addis Ababa, Ethiopia between $31^{\text {st }}$ August and $4^{\text {th }}$ September. McIntire and Staves JES1987.

11 Food and Agriculture Organisation. Employment of Draught Animals in Africa. FAO Rome, 1972.

12 Virmani SM, Sahrawat KL and JR Burford Physical and chemical properties of vertisols and their management. ICRISAT Pantecheru, Andhra Pradesh India, 1982; 80-93. Accessed on 15th May 2015 from oar.icrisat.org/4038/1/0048.pdf. 


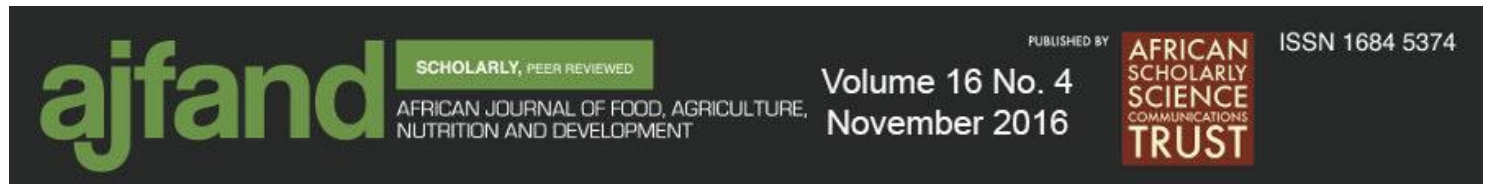

13 District Agricultural Engineer Kirinyaga County. Personal Communication, 2014.

14 Ikitoo EL The influence of surface water management and fertilizer use on growth and yield of maize in vertisols in Kenya. PhD Thesis Moi University. 2008.

15 Sigunga DO Fertilizer nitrogen use efficiency and nutrient uptake by maize in vertisols in Kenya. PhD Wageningen University, 1997.

16 International Soil Reference and Information Centre (ISRIC), (Undated). Vertisols (VR).

www.isric.org/isric/webdocs/docs/major_soils_of_the_world/set3/vr/vertisol.pd f. Accessed in August 2015.

17 Goe MR Animal Traction and Smallholder Farming in Ethiopia. PhD Thesis Department of Animal Science, Cornell University, Ithaka, New York USA.1987.

18 Jutzi SC, Anderson FM and A Abiya Low Cost Modification of the traditional Ethiopian type plough for land shaping and surface drainage of heavy clay soils. Preliminary results from on-farm verification. ILCA Bulletin no 27:28-31 Addis Ababa 1987.

19 Ikitoo EC Vertisols management for arable cropping in Kenya: Occurrence, management problems and improved drainage management practices. KARI Annual report, 1997. 